\begin{tabular}{lll} 
KULTURA & $\begin{array}{l}\text { POLSKA A KADEMIA NAUK } \\
\text { KOMITET SOCJOLOGII }\end{array}$ & ISSN 0023-5172 \\
i & $\begin{array}{l}\text { INSTYTUT STUDIÓW POLITYCZNYCH } \\
\text { SPOLECLENSTWO nr } 2\end{array}$ & WIDZIANE W MIEŚCIE \\
\hline
\end{tabular}

MICHA£ DOBROŁOWICZ

Uniwersytet Warszawski

\title{
CZY WIDZIALNOŚĆ JEST GWARANCJĄ SUKCESU? SKUTECZNOŚĆ DZIAŁAŃ MARKETINGOWYCH W PRZESTRZENI MIEJSKIEJ
}

Łatwo wyobrazić sobie sytuację, w której odbywa się zebranie firmy X. Pracownicy przedsiębiorstwa nie przychodzą na to spotkanie w najlepszych nastrojach. Jeden z głównych omawianych problemów stanowią bowiem przyczyny wyników finansowych firmy, które są zdecydowanie poniżej oczekiwań zarządu, dyrektorów i menadżerów. W trakcie dyskusji ktoś może podsunąć myśl brzmiącą mniej więcej tak: „Może przyczyną problemu jest to, że nas w ogóle nie widać w mieście?”. W ślad za taką sugestią pójść może kampania marketingowa polegająca na uwidacznianiu logo i nazwy firmy na billboardach w różnych częściach aglomeracji, przyklejaniu reklam na autobusach i taksówkach czy emitowaniu spotów reklamowych przed seansami filmów w śródmiejskich multipleksach. Byłyby to działania mające na celu uwidocznienie w przestrzeni miejskiej danej firmy, jej produktów lub samej marki.

Opisana sytuacja jest wymyślona, ale powstała ona na podstawie relacji kilku osób - pracowników niezależnych od siebie firm, które stanęły przed wyzwaniem poprawienia swoich wyników sprzedażowych. Zarówno te relacje, jak i wyobrażenie opisanej sytuacji stały się punktem wyjścia do postawienia pytania stanowiącego główny problem dalszych rozważań: czy widzialność jest rzeczywiście warunkiem sukcesu ekonomicznego? Idąc dalej: czy widzialność W wielkim mieście zawsze wspiera taki sukces? Czy jednak czasami nie ma nań wpływu, a w staraniach o jego uzyskanie bywa wręcz przeciwskuteczna?

Tak sformułowany problem chcę spróbować rozwiązać odwołując się do czterech koncepcji i wywodzących się z nich pojęć. Pierwszą z nich jest kon- 
cepcja ekonomii uwagi George'a Franka (Frank, Cook 1996), w myśl której uwaga jest dobrem nie mającym, w przeciwieństwie do innych zasobów ekonomicznych, swojego substytutu i bardzo trudno jest je czymkolwiek zastąpić. Druga dotyczy typu audytorium, do jakiego docierają prezentowane w mieście wizualne przekazy reklamowe. Trzecia perspektywa odsyła do pojęcia kultury dystrakcji, której cechą charakterystyczną jest „niezdolność zanurzonych w niej jednostek do koncentracji na czymkolwiek, do wyłączności uwagi i jej skupienia na określonym obiekcie przez dłuższy czas" (Krajewski 2007, s. 4), oraz opisywanych przez różnych autorów konsekwencji funkcjonowania w ramach tej kultury (Wernick 1992). Czwartą płaszczyznę, na której poszukiwane będą odpowiedzi na postawione pytania, stanowi koncepcja dotycząca tego, jak omija się problem widzialności w działaniach marketingowych. Kluczowe $\mathrm{w}$ tej części analiz będzie pojęcie spreadability (rozprowadzalność) zaproponowane przez Henry'ego Jenkinsa (Jenkins, Ford, Green 2013). Na koniec zastanowię się nad sytuacją, w której kampanie reklamowe odwołują się do innych zmysłów niż wzrok. Temu problemowi przyjrzę się wykorzystując, opisywaną między innymi przez Marka S. Szczepańskiego i Weronikę Ślęzak-Tazbir (2008, s. 18-40), perspektywę osmosocjologiczną.

\section{WIDZIALNOŚĆ REKLAM A EKONOMIA UWAGI}

U podstaw rozwijanej przez przywołanego George'a Franka ekonomii uwagi leży założenie, że każda informacja trafiająca do konkretnego odbiorcy zużywa jego uwagę, a jednostkowe możliwości związane z gospodarką uwagą są stałe i, co więcej, ograniczone. Uwaga odbiorcy jest zatem bardzo cennym dobrem, o które rywalizować muszą autorzy i nadawcy kolejnych informacji. Mamy do czynienia, używając języka ekonomistów, $z$ wysokim kosztem alternatywnym: skupienie uwagi na idei o nazwie $\mathrm{X}$ oznacza mniejsze zasoby lub nawet całkowity brak uwagi, jaka mogłaby zostać poświęcona przedmiotowi czy idei nazywającej się Y. W takim ujęciu uwaga jest dobrem, dla którego bardzo trudno znaleźć jakikolwiek substytut. Można powiedzieć, że należy ona do dóbr niezastępowalnych (non-substitutability).

Twórca tej koncepcji podkreśla, jak istotna jest uwaga i do czego może ona służyć. Frank stawia tezę, zgodnie z którą we współczesnym społeczeństwie jednostki cechuje duża potrzeba jednostkowego wyróżnienia się, bycia kimś wyjątkowym, oderwania się od tego, co masowe (nawet jeśli jest to masowe bogacenie się społeczeństwa), wzniesienia się ponad innych dzięki swojej widoczności (prominence). Aby to się udało, jednostka musi wykorzystać swoją uwagę, ponieważ z jednej strony czujnie obserwuje, jak inni się zachowują (ubierają, mówią, konsumują, kreują itd.), a z drugiej strony na podstawie tego, co zdoła dostrzec, buduje własną autonomię i próbuje zainteresować sobą innych. Można zauważyć $\mathrm{w}$ tym paradoks polegający na tym, że jednostka próbująca skupić 
na sobie uwagę innych sama staje się mniej uważna i mniej uważnie rejestruje to, co dzieje się dookoła niej.

Przedstawiony na podstawie teorii Franka opis współczesnej jednostki pokazuje, kim jest „posiadacz uwagi” (czy precyzyjniej: „dystrybuujący własną uwagę"), o którą tak mocno zabiegają przywołani na początku uczestnicy wyimaginowanego zebrania marketingowego. W świetle ekonomii uwagi ich wysiłki są $\mathrm{w}$ pełni uzasadnione, co więcej, uzasadniony jest też fakt, że energię i czas poświęca się właśnie na „uwidzialnienie” danej marki, a nie na przykład na analizę wartości merytorycznej czy praktycznej jej produktów. Jak zauważa Marek Krajewski (2007, s. 5), zdobyta w ten sposób uwaga ma „[...] tendencję do autoreprodukcji i to poszerzonej (im większy poziom zainteresowania gwiazdą, tym bardziej pragną jej producenci wszelkich dóbr, a im bardziej jej pragną, tym bardziej jest nadobecna) [...], jak i jest zaraźliwa (im większe zainteresowanie gwiazdą, tym większa jej zdolność do budzenia zainteresowania tym wszystkim, czego się dotknie)". To z kolei sprawia, że odczuwana wartość tego, co robimy, jest uzależniona od (niezależnych od nas) zjawisk związanych $\mathrm{z}$ ekonomią uwagi. Czy jednak w codziennej, miejskiej praktyce sprawdzają się zasady, na które ona wskazuje? Andrew Wernick (1992) pisze o istnieniu w mieście specyficznej, kapitalistycznej „kultury promocyjnej”, w obrębie której ścierają się ze sobą siły różnych dystraktorów. Należą do nich zarówno elementy mające uwidocznić obecność zarządzających miastem, reprezentacje świata sztuki, jak i właśnie przekazy reklamowe, nazywane niekiedy „wizualnym skażeniem" (visual polution). Na reklamy wizualne można spojrzeć jak na jeden $z$ wielu dystraktorów, których jedyną funkcję stanowi przyciągnięcie uwagi (zwykle krótkotrwałe) uwodzonego w ten sposób odbiorcy. Warto zauważyć, że często odbywa się to przy użyciu samego miasta — przez wbudowanie reklamy na stałe w konkretny wycinek przestrzeni miejskiej. David Bernstein (2006, s. 114) pisze, że „niektóre billboardy z czasem zaczynają pełnić rolę punktów charakterystycznych w krajobrazie miasta". Według tego znawcy sztuki plakatu reklamowego każdy twórca reklamy (oraz klient tego twórcy) dąży do tego, żeby produkt jego pracy został zapamiętany w takim stopniu, że staje się niezbędnym elementem przestrzeni miasta lub wręcz pełni rolę punktu orientacyjnego, dzięki któremu ludzie są w stanie określić, w jakim miejscu się znajdują. Tezę tę potwierdzają badania przeprowadzone przez Małgorzatę Jakiel (2013, s. 57), w których potwierdzono, że „percepcja reklam jest nierozerwalnie związana z zapamiętywaniem samych ulic, przy których są one lokalizowane".

Wpływy rynku i działania komercyjne wkraczają mocno w przestrzeń miejską i zmieniają jej wygląd. Jak pisze Michael J. Sandel w książce Czego nie można kupić za pieniadze (2012, s. 223): „[...] strategicznie rozmieszczone ekrany wideo pozwalają reklamodawcom przyciągnąć uwagę klientów w czasie gdy nawet najbardziej zaganiani czy roztrzepani z nich nie mają wyboru - muszą stać i czekać [...] przy dystrybutorze na stacji benzynowej, a nawet przy pisu- 
arach $w$ restauracjach, barach i innych miejscach publicznych". Sandel podaje też przykłady, w których reklamodawcy nadają nazwy najstarszym stacjom metra (w 2009 roku zarząd nowojorskiego zakładu transportu zbiorowego sprzedał bankowi Barclays za cztery miliony dolarów prawo do nadania swojej nazwy jednej z najbardziej uczęszczanych stacji w Brooklynie), a miasta i stany starały się o sponsoring korporacyjny dla publicznych parków, szlaków krajobrazowych i rezerwatów przyrody. Na przykład North Face, producent wysokiej klasy ubrań dla turystów, umieszcza swoje logo na symbolach oznaczających trasy w parkach publicznych w stanach Wirginia i Maryland. Inne głośne przypadki podobnych działań to logo sieci restauracji KFC umieszczane w amerykańskim stanie Indiana na hydrantach oraz wizerunki słoików masła orzechowego firmy Skippy odciśnięte na piasku na plaży Seaside Heights w New Jersey (Sandel 2012, s. 231-234). Na początku XXI wieku głośna była również historia z Karoliny Północnej, gdzie jedna $z$ firm oferowała policji nowe, w pełni wyposażone radiowozy za jednego dolara rocznie pod warunkiem, że po mieście radiowozy te będą jeździły pokryte jej reklamami i logotypami (podobnie jak samochody biorące udział w wyścigach samochodowych). Zjawiska tego typu określane są mianem „urynkowienia miast” (Sandel 2012, s. 231-234).

Jak odbywa się to $\mathrm{w}$ praktyce, $\mathrm{w}$ dużej mierze zależy od tego, kto należy do grupy odbiorców, do których w przestrzeni miejskiej trafiają reklamy.

\section{ZNACZENIE WIDZIALNOŚCI A TYP AUDYTORIUM}

„Audytorium” jest podstawowym terminem w amerykańskich badaniach nad komunikowaniem, „stosowanym - jak pisze Tomasz Goban-Klas (1999, s. 207) — jako nazwa zbiorowa dla oznaczenia «odbiorców» w prostym sekwencyjnym modelu komunikowania". Według przywoływanego przezeń Martina Allora (1988), audytorium nie zajmuje rzeczywistej przestrzeni, istnieje jedynie $\mathrm{w}$ dyskursie teoretycznym. Opisując $\mathrm{w}$ ten sposób audytorium Allor ma na myśli przede wszystkim czytelników prasy, telewidzów czy radiosłuchaczy. Nie wolno zapominać jednak o tych, którzy odbiorcami reklam stają niecelowo, w czasie zwykłego spaceru ulicami miasta.

Jeżeli odbiorcy dobrze znają lokalizację reklamy (adres budynku, na którego ścianie zawieszony jest billboard, trasę autobusu, na którego zewnętrznym fragmencie zobaczyć można logo danej firmy lub dane siedziby kina, w którym wyświetlany jest spot reklamowy), to ich cechy jako audytorium wydają się nieco inne. Pozwala to określić, kto stanowi grupę „widzących” daną reklamę grupę osób, do których oczu reklama ta dociera (pracujący w okolicy wywieszonego billboardu, stale jeżdżący linią autobusową w jego okolicy, osoby, które były na seansie $\mathrm{w}$ danym kinie). Audytorium to ma kilka cech, o których pisał Gabriel Tarde w głośnej pracy Opinia $i$ tłum (1904). Tarde wprowadził i omawiał w niej pojęcie publiczności, medialnej zbiorowości odbiorczej określanej jako „zbiorowość czysto duchowa jednostek rozproszonych i fizycznie oddzie- 
lonych, których spoistość jest spoistością czysto myślową" (cyt. za: Goban-Klas 1999, s. 209).

Definicja, którą zaproponował Tarde, jest krytykowana przez współczesnych badaczy, ponieważ odpowiada raczej kulturowej sytuacji końca XIX i początku XX wieku, gdy prasa docierała tylko do wąskiej i elitarnej grupy odbiorców, a proces jej umasowienia dopiero się zaczynał (Szczurkiewicz 1970 [1934], s. 298-326; zob. też Goban-Klas 1999, s. 210). Wraz z upowszechnianiem się dostępu nie tylko do prasy, ale przede wszystkim do radia i kina nie tylko rosła liczebność publiczności, zwiększała się także jej heterogeniczność oraz anonimowość jej członków. Co więcej, publiczność ta traciła cechy, które sprawiały, że była postrzegana jako zbiorowość wyselekcjonowana (Tudor 1970, s. 92-100). Z pewnością trudno ją określić, jak chciałby Goban-Klas, jako "autentyczne audytorium masowe” (audience) — nie jest już wyodrębniana ze względu na cechy społeczno-kulturowe. Nicolas Abercrombie i Brian J. Longhurst (1998) publiczność tego rodzaju nazywają rozmytą i rozproszoną. Po pierwsze, ze względu na jej zróżnicowanie, a po drugie, ze względu na wymienność ról nadawczych i odbiorczych - osoby tworzące to audytorium nie tylko odbierają sygnały, ale są też ich nadawcami, gdy występują przed innymi członkami audytorium. Należy zwrócić uwagę na nasycenie środowiska miejskiego przekazami, co sprawia, że bardzo trudno jest oddzielić momenty, w których jesteśmy odbiorcami, od tych, w których ten proces nie występuje.

Wydaje się, że audytorium takie można porównać do grupy widzów raczej kinowego seansu niż teatralnego spektaklu, ponieważ reklama, podobnie jak pokaz filmu, w zdecydowanej większości jej form (zdjęcie na billboardzie, reklamowy film, wyglądająca w określony sposób ulotka, na której wydrukowane jest hasło-slogan firmy) nie zmienia się w kolejnych egzemplarzach. Idąc dalej - porównujemy je raczej do grupy słuchaczy konferencyjnych wystąpień, którzy co pewien czas sami zabierają głos. Jednak widzowie w kinie zbierają się, aby obejrzeć film i, jak pisze Philippe Delerm (2004, s. 46), „celebrować kinową płaszczyznę", w przeciwieństwie do odbiorców reklam, dla których zapoznanie się z marketingowym przekazem nie stanowi głównego celu przebywania w danym miejscu. Wręcz przeciwnie, reklamowy komunikat musi, jak wskazuje teoria Franka, rywalizować o uwagę odbiorców z innymi bodźcami. Sytuację wizyty w kinie cechuje izolacja, dobrowolność i odcięcie się od zewnętrznego świata, czyli jest przeciwieństwem pobytu w centrum miasta.

Wątpliwości wokół przywołanego porównania prowokują do określenia audytorium widzialnych reklam jako skupionego (spolaryzowanego) agregatu. Jest to pojęcie, którego autorem jest Harold Lasswell (1948, s. 32-51), opisuje ono zbiór ludzi, których myślenie i zainteresowania identyczne podniety mogą nastawiać $\mathrm{w}$ jednym kierunku. W socjologicznych interpretacjach tej definicji, znajdujących zastosowanie w badaniach nad komunikacją, mówi się o tym, że „skupiony agregat” obejmuje odbiorców, którzy w arbitralnie wybranym okresie (na przykład w czasie trwania kampanii reklamowej) zapoznali się 
z danym przekazem (Goban-Klas 1999, s. 211). Przekaz zyskuje w ten sposób charakter asynchroniczny (dociera do odbiorców w różnym czasie) i zsumowany (jego efekt ocenia się sumując odbiorców w kolejnych dniach, tygodniach i miesiącach). Mówiąc o odbiorcach widzialnych reklam warto zwrócić uwagę na dwie kwestie. Po pierwsze, odbiorcy ci są traktowani zazwyczaj jako audytorium potencjalne, które obejmuje osoby zdolne do odbioru przekazu reklamowego głównie dzięki temu, że znajdują się w jego zasięgu. Po drugie, w ich opisach używa się terminu „audytorium jako rynek” (McQuail 1994). Audytorium to stanowi agregat indywidualnych, zatomizowanych konsumentów i nie ma skrystalizowanej tożsamości.

Wydaje się, że odbiorców reklam można scharakteryzować podobnie jak John Fiske (2010), który opisuje kulturę popularną jako kulturę odbioru. Odbiorcy są przedstawiani w tym ujęciu jako osoby aktywne, krytyczne i kreatywne, według własnych potrzeb społecznych, politycznych czy emocjonalnych przekształcające materiał oferowany przez podmioty będące u władzy. Kluczowi dla tej koncepcji są właśnie odbiorcy, którzy tworzą popkulturę. Dzieje się to na zasadzie zawłaszczania, przekształcania i rekontekstualizowania tekstów kultury popularnej, na przykład reklamowych. Odbiorcy tacy przeciwstawiają się w ten sposób standaryzacji i homogenizacji (Kobus 2014), akcentują swoją autonomię kulturową.

Chcąc powiedzieć więcej o wpływie widzialnych reklam na ich odbiorców, trzeba przyjrzeć się warunkom społecznym, w jakich wpływ ten zachodzi. Posłużę się dwoma pojęciami: pierwsze to „kultura dystrakcji”, a drugie spreadability (rozprowadzalność).

\section{WIDZIALNOŚĆ REKLAM W KULTURZE DYSTRAKCJI}

Jan Gehl w książce Miasta dla ludzi (2010, s. 39) analizuje znaczenie różnych zmysłów dla funkcjonowania w wielkim mieście. Omawiając zmysł wzroku wymienia przykłady niskich budynków, które dużo lepiej niż budynki wysokie odpowiadają ludzkim zmysłom, w toku ewolucji bowiem zmysły dostosowały się do tego, że właściciel poruszał się liniowo i poziomo. Gehl posłużył się przykładem sytuacji kupna biletu do teatru. Jego cena jest niższa, gdy oferowane miejsce nie znajduje się na poziomie wzroku widzów. Poziome spektrum widzenia człowieka ma też inne konsekwencje: gdy idziemy wzdłuż fasad, to elementy umieszczone na parterze, na przykład reklamy, mogą zapewnić dużo bodźców i wrażeń. W typowej sytuacji człowiek idący z prędkością 4-5 kilometrów na godzinę i zauważający znajdujący się 100 metrów przed nim szyld reklamowy ma około 60-70 sekund do bezpośredniego spotkania z tym szyldem (Gehl 2010, s. 43). W tym czasie może ocenić to, co spotyka, i zareagować. Na podstawie tego typu obliczeń Gehl pisze o „architekturze 5 kilometrów na godzinę”, za pomocą której można opisać „marketing 5 kilometrów na godzinę”. Bazowałby on na „kombinacji detali, ludzkich twarzy i aktywności przyczyniających 
się do bogatego i pełnego doświadczenia zmysłowego" (Gehl 2010, s. 44). Podobnych sytuacji przyciągania uwagi w zależności od tego, z jaką prędkością porusza się odbiorca bodźca jest wiele. Na przykład kierowcy na autostradzie zwalniają, gdy przejeżdżają obok wypadku, który wydarzył się na sąsiednim pasie, aby móc przyjrzeć się, co dokładnie się wydarzyło. Takie sytuacje wpisują się w kulturę określaną przez Marka Krajewskiego (2007, s. 1) jako kultura dystrakcji, „[...] której osią są nieustannie ponawiane próby zmiany przedmiotów jednostkowego zainteresowania, odrywania nas od tego, na czym jesteśmy aktualnie skoncentrowani i proponowania nowych atrakcji godnych naszego czasu, namysłu i pamięci".

Odbiorca reklamy, przedstawiciel przywołanego audytorium rynku (spolaryzowanego agregatu Lasswella), ma — jak się wydaje — „nasycone Ja” (the saturated Self). Tłumacząc proces „społecznego nasycania” Kenneth J. Gergen (2009, s. 94) pisze: „dzięki zaawansowanej technologii naszego wieku stale zwiększa się liczba i różnorodność związków, w które się angażujemy, rośnie potencjalna częstotliwość kontaktów, stale nasila się również ich zewnętrzna intensywność i trwałość w czasie. [...] Wzrost ten osiąga wartości maksymalne". W obliczu takich sytuacji dojść może do anestezji, czyli niezdolności do odbierania wrażeń ze względu na ich nadmiar (Welsch 1998, s. 520-546), lub sytuacji, którą Gergen (2009, s. 106) określa mianem multifrenii, czyli stanu, w którym jednostka ma tak dużo różnych propozycji i możliwości, że zaczyna rozszczepiać się na wiele autoinwestycji. W konsekwencji powodzenie działań marketingowych zaczyna zależeć od tego, czy zastosowana zostanie odpowiednio skuteczna strategia przyciągnięcia uwagi odbiorcy — człowieka znajdującego się w pełnym dystraktorów stanie multifrenii. Nadawca komunikatu reklamowego powinien zatem wyróżnić to, co przekazuje, przerywając monotonię wysyłanych bodźców, sprawić, że jego komunikat wyodrębni się w polu percepcyjnym odbiorcy. Może dziać się to poprzez ek s ponow a nie a mbiwalentności, czyli tego, co jest dwuznaczne, z czym odbiorca może mieć problemy poznawcze (Krajewski 2007, s. 6). W takiej strategii łatwo mogą być wykorzystane elementy wizualne (niejednoznaczności płciowo-seksualne, wygląd nieadekwatny do wieku prezentowanej osoby, niezwykłe elementy życia gwiazd lub, dla kontrastu, eksponowanie zwyczajnych elementów codziennego życia znanych osób). Stosowanie w przekazach reklamowych obecności celebrytów-gwiazd bliskie jest temu, co można nazwać t a kt y ką h u by (Krajewski 2007, s. 6), która polega na wykorzystywaniu tego, że widzialna i powszechnie rozpoznawalna jest jakaś osoba lub zjawisko. Opisać to można potocznie jako ogrzewanie się w blasku kogoś, kto jest popularny. Podczas planowania strategii reklamowych można sięgnąć po różne sposoby: zachęcanie znanej osoby do widocznego, publicznego używania reklamowanych produktów czy nawet podkreślanie w spotach reklamowych bliskich relacji z tą osobą.

Strategia kumulacji uwagi mieszkańca wielkiego miasta może polegać na sformułowaniu odpowiedniego hasła odnoszącego się do korzyści, jakie od- 
biorca może uzyskać decydując się na dany produkt, lub na przekonywaniu obiorcy, że jako adresat reklamowanej oferty za jej sprawą zostanie potraktowany jak ktoś wyjątkowy. Powstaje pytanie, czy słowne obietnice przekazywane w formie tekstu będą miały siłę przebicia wśród wielkomiejskich bodźców. Należy zaznaczyć, że odbiorcy dysponują kompetencjami, ponieważ zazwyczaj mieli już przed oczami setki reklam. Jednocześnie upowszechnia się wiedza na temat środków perswazyjnych i chwytów marketingowych, które mają na celu przyciągnięcie ich uwagi (Jakiel 2013).

$\mathrm{Na}$ podstawie przywołanych strategii kumulacji uwagi można powiedzieć, że samo „uwidzialnienie” produktu nie tylko nie gwarantuje mu sukcesu, lecz staje się momentem próby, w którym o sukcesie zdecydować może kontekst, $\mathrm{w}$ jakim produkt ten zostanie przedstawiony (ludzie, hasło, perswazyjny komunikat). Z takim podejściem korespondują prace Henry'ego Jenkinsa na temat różnego rodzaju „rozprowadzalności” (spreading) z założenia niewidocznych, idei.

Jenkins zajmuje się przede wszystkim zjawiskiem określanym jako „marketing wirusowy" (viral marketing), polegającym na doprowadzeniu do sytuacji, w której klienci sami między sobą rozpowszechniają informacje dotyczące reklamowanych usług czy produktów. Jenkins tłumacząc, w jaki sposób rozprowadzane są rozmaite idee, $\mathrm{w}$ tym marketingowe, powołuje się na zoologa i etologa Richarda Dawkinsa, który stwierdził, że współcześnie to nie ludzie zdobywają idee, ale idee zdobywają ludzi. To potencjalni klienci (konsumenci) w tym modelu są aktywni i to oni stanowią przekaźnik różnego rodzaju komunikatów. Komunikaty te są rozprowadzane na zasadzie mechanizmu podobnego jak ten, który towarzyszy działaniu patogenów (Jenkins 2009). Praktyczne zastosowanie tego typu strategii można zaobserwować nie tylko na przykładzie internetowych memów czy wirusów. Widać je również w działaniach marketingowych, gdy klub rekrutuje nowych członków wykorzystując „marketing szeptany", zachęcając dotychczasowych klubowiczów, aby zaprosili znajomych na „dzień próbny”, w nadziei na to, że wykupią oni, wzorem swoich kolegów, kartę klubową. Można powiedzieć, że jest to uwidacznianie marki w przestrzeni publicznej, ale audytorium jest tutaj wąskie, nieprzypadkowe, nie każdy ma szansę się do niego dostać, tak jak nie każdy ma znajomych wśród członków danego klubu. Wracając do porównania kinowego, osoby, do których dotrze marketingowy komunikat (upostaciowiony choćby w formie wizytówki z logo firmy), przypominają raczej widzów zamkniętego, jednorazowego pokazu przedpremierowego odbywającego się w kinie studyjnym niż fanów popularnej superprodukcji wyświetlanej we wszystkich multipleksach.

Taki sposób rozprowadzania informacji o marce ma odniesienie do strategii kumulacji uwagi w kulturze dystrakcji. Strategia ta, jak określa ją Krajewski $(2007$, s. 6), polega na zapewnianiu odbiorcy, że nadawca reklamowego przekazu interesuje się nim, co może objawiać się „[...] w bardzo prostych frazach, takich jak «jesteście najlepszą publicznością na świecie» czy «nagrałem tę pły- 
tę z myślą o Was», ale także we współpracy z fanklubami, korespondowaniu $z$ wielbicielami, organizowaniu dla najwierniejszych z nich kameralnych i quasi-prywatnych spotkań”. Budowanie poczucia wyjątkowości u odbiorcy może odbywać się też poprzez uwidacznianie konkretnych produktów (choćby w formie reklam) w wybranych miejscach, w których nie każdy bywa. Magazyn adresowany do osób z wysokimi dochodami może być promowany jedynie w filharmoniach lub kilkugwiazdkowych hotelach, co jest przykładem próby przezwyciężenia sytuacji nadmiaru wielkomiejskich dystraktorów - w takich miejscach bodźców reklamowych jest dużo mniej niż w centrum miasta. Można jednak zadać pytanie, czy w takiej sytuacji nie pojawi się zjawisko pułapki ekskluzywnego, spajającego (bounding) kapitału społecznego (Putnam 2008), który w odróżnieniu od kapitału łączącego (bridging) działa tylko w obrębie danej grupy, nie wychodząc na zewnątrz i w efekcie nie docierając do osób znajdujących się daleko. $\mathrm{Z}$ marketingowego punktu widzenia takie osoby (niebywające w filharmonii, niemieszkające w kilkugwiazdkowych hotelach) też mogłyby być zainteresowane reklamowaną ofertą.

Zakładam tutaj, zgodnie $z$ intuicjami przywołanego Johna Fiske, że przekaz popkultury (w tym przekaz reklamowy) najlepiej działa wtedy, gdy zostaje świadomie przetworzony. Warto pamiętać także o tym, że jest to tylko jeden $z$ modeli przetwarzania danych sensorycznych (ścieżka centralna) (zob. Petty $\mathrm{i}$ in. 2004). Konkurencyjny model polega na raczej płytkim przetwarzaniu informacji, dostrzeganiu ich tylko kątem oka, za czym idzie nieświadome ich zapamiętywanie (ścieżka peryferyjna). W tę drugą ścieżkę może wpisywać się wytwarzanie pożądania przez nadawców komunikatów.

\section{REKLAMOWANIE JAKO WYTWARZANIE POŻĄDANIA}

Warto zastanowić się, czy za popularną formę reklamy można uznać stosowane w przestrzeni miejskiej praktyki mające na celu wytworzenie u „użytkowników miasta" pożądania. Przykładami takich działań mogą być przeszklone siłownie w centrach miast, często usytuowane na wysokich piętrach galerii handlowych, gdzie pasażerowie komunikacji miejskiej czy kierowcy samochodów mogą zobaczyć szczupłe sylwetki osób poruszających się na bieżniach (i w efekcie nabrać ochoty na wykupienie karnetu na siłownię), lub przeszklone drzwi drogich restauracji, w których z perspektywy ulicy można dostrzec wygląd potraw, ubrania gości czy instrumenty, jakich używają grający w restauracji muzycy. Widzialność (jak wygląda sytuacja wewnątrz) stanowi tutaj nęcący czynnik, który ma zwiększyć atrakcyjność konkretnej usługi. „Wytwarzanie pożądania” może się odbywać nie tylko za pośrednictwem tego, co widzialne. Socjologowie analizują obecnie także przekazy oddziałujące na zmysły inne niż wzrok. Jeden $z$ wielu przykładów stanowi „sztuczne aromatyzowanie przestrzeni, na przykład przed sklepami z pieczywem czy kawą, mające na celu przyciągnięcie klienta „niepotrafiącego się oprzeć” (Szczepański, Slęzak-Tazbir 2008, s. 35). 
Chodzi tu także o to, że pewne przekazy zapamiętujemy nawet wówczas, gdy informacji w nich zawartych nie przetwarzamy w sposób świadomy. Jest to jedna $z$ podstawowych form przetwarzania komunikatów reklamowych.

Warto mieć na uwadze, choć brzmi to jak truizm, że widzialność we współczesnym marketingu dotyczy też działań prowadzonych $\mathrm{w}$ internecie. Wielu badaczy analizuje, $\mathrm{w}$ jaki sposób przedsiębiorstwa korzystają $\mathrm{z}$ internetu, żeby budować swój wizerunek i - korzystając $z$ niedrogich kanałów komunikacji — zbierać informacje od swoich klientów (Batorski 2012, s. 271-286). Wyniki badań prowadzonych przez Interdyscyplinarne Centrum Modelowania Matematycznego i Komputerowego na Uniwersytecie Warszawskim pokazały, że dbałość o widoczność w internecie w największym stopniu wykazują przedsiębiorstwa zatrudniające powyżej pięćdziesięciu pracowników, działające w branży handlowej oraz nastawione na klientów indywidualnych (Pacuska i in. 2015, s. 85-100). Dbałość ta może przybierać różne formy: od działań mających na celu pozycjonowanie strony firmy w wyszukiwarkach internetowych przez aktywność na portalach społecznościowych po wykupywanie płatnych reklam online. Mechanizm polegający na tym, że widzialność zwiększa atrakcyjność danej osoby, produktu lub usługi, można odnieść też do działalności naukowej. W artykule Jak zwiększyć widoczność swojej publikacji naukowej w internecie? (Maczuga, Przyłuska 2012, s. 391-393) czytelnik znajduje kilkanaście konkretnych wskazówek, co powinien zrobić, żeby jego praca była skuteczniej wyszukiwana przez potencjalnych odbiorców. Kolejne rady dotyczą tego, jak wykorzystać elementy ASEO (academic search engine optimization - optymalizacja wyszukiwarki internetowej), żeby przygotować artykuł naukowy lub raport w taki sposób, aby ten był dobrze zaindeksowany w bazach danych. Efektem ma być zwiększenie widoczności własnych osiągnięć $\mathrm{w}$ internecie, a motywem dążenie, żeby dać się zauważyć w sposób zgodny z przyjętymi standardami (Maczuga, Przyłuska 2012, s. 392).

\section{MARKETING NIE TYLKO WIZUALNY}

O wielkomiejskiej reklamie wizualnej mówi się, że buduje w miastach nowe opowieści i — jak pisze Michel de Certeau (2011, s. 132) — „mnoży nasze pragnienia i wspomnienia, opowiadając je przy pomocy słownika przedmiotów konsumpcyjnych. Rozwija na ulicach i w podziemiach metra niekończący się dyskurs naszych epopei". Obok takiego myślenia pojawia się idea, zgodnie z którą reklama ma siłę umacniającą współczesną władzę, nawet gdy zawiera elementy przeciwko tej władzy skierowane, jeśli wpisuje się $\mathrm{w}$ działania zgodne $z$ ekonomią uwagi (Krajewski 2010, s. 187). W obliczu założeń teorii Franka i cech kultury dystrakcji prawdziwy może okazać się wniosek, że widzialne aspekty komunikatów reklamowych są przeceniane. Uwagę odbiorców można próbować kumulować za pomocą innych technik i odwołując się do innego niż świadomy modelu przetwarzania informacji. 
W socjologii coraz więcej mówi się o perspektywie osmosocjologicznej, która budowana jest na gruncie założeń sugerujących, że „zapach przestrzeni, gdy skoncentrować się na nim, jest czasem bardziej charakterystycznym wyznacznikiem aniżeli niejeden budynek czy droga" (Szczepański, Ślęzak-Tazbir 2008, s. 19). „W każdym momencie życia [...] wdychamy rozmaite zapachy, ich odczuwanie towarzyszy każdej podejmowanej przez nas czynności i ma miejsce w każdym możliwym do pomyślenia kontekście" - pisze Diane Ackerman (1994, s. 18), zwracając uwagę na to, że oddychanie (i stanowiące jego konsekwencję wdychanie zapachów) stanowi warunek przeżycia. Krajewski (2010, s. 246) wymienia zapachy, których pojawienie się jest przykładem zmiany czasów. Wśród nich są wonie niemal nieznane w Polsce przed rokiem 1989, takie jak zapach grilla, odświeżaczy powietrza, luksusowych butików, indyjskich kadzideł czy nawet czystych miejskich toalet. Proces dezodoryzacji nie pozostał bez wpływu na działania marketingowe, gdyż można zauważyć przejawy procesów ujednolicania zapachów. Cytowany w 2001 roku przez tygodnik „Newsweek" niewidomy tak relacjonował swoje wrażenia węchowe $z$ wizyty w sklepie: „Polska ulica pachnie dziś inaczej niż za czasów PRL-u. Trudniej jest się domyślić, przed jakim sklepem stoję. [...] Teraz wszystkie sklepy pachną jednakowo, bo są myte i spryskiwane środkami o zapachu cytrynowym i kwiatowym" (Kalbarczyk 2001). Takie relacje wskazują, że wobec ujednolicenia lub upodobnienia zapachów przestrzeni handlowych (stanowiących spory wycinek miast) rośnie szansa przyciągnięcia uwagi nietypowym, ale przyjemnym zapachem. Zajmujący się tym nurtem zwracają jednak uwagę na marginalizację woni i zapachów jako danych zmysłowych czy wręcz ich deprecjację jako przedmiotu analizy (Szczepański, Ślęzak-Tazbir 2008; Krajewski 2010). W myśl koncepcji ekonomii uwagi Franka można spodziewać się, że odpowiedni aromat mógłby stać się jednym z narzędzi wywołania u klienta poczucia, że jest kimś wyjątkowym, innym niż pozostali klienci, bo kieruje się w swoich decyzjach nie tylko finansową kalkulacją czy kolorem produktu, ale związanym z nią zapachem. Paola Wendland (2006) na podstawie swoich badań przekonuje, że szczególnie podatni na działanie zapachów są klienci niezdecydowani, a miły dla nich zapach $\mathrm{w}$ większej mierze niż na decyzję o kupnie produktu wpływa na to, że pozostają w sklepie dłużej. W świetle koncepcji kultury dystrakcji należy uznać to za argument przemawiający na korzyść „uzapachowienia” danej marki, bo oznacza, że aromat skumulował uwagę klientów skuteczniej niż inne elementy.

Warto zadać pytanie, czy odwołanie się w reklamie do zmysłów, które nie są tak dobrze przepracowane kulturowo jak wzrok, oznacza nie tylko zmianę dystraktora (dane wzrokowe zastępowane są przez dane zapachowe), lecz także zmianę modelu oddziaływania reklamy. Dalej można zastanowić się nad tym, jak na „użytkownika miasta”, czyli potencjalnego konsumenta, zadziała zjawisko polegające na nadmiarze zapachowych bodźców (zanieczyszczenie osmotyczne). Zwracają na to uwagę Marek Szczepański i Weronika Ślęzak-Tazbir pisząc, że „zaniepokojenie wzbudza zapach Marszałkowskiej będący połączeniem 
kebaba, perfum z Galerii Centrum i specyficznych zapachów z pobliskich peep-showów i sex barów". Stosując osmotyczne podejście do marketingu miejskiego można zadać pytanie, gdzie leżą granice wykorzystania zapachów w reklamie i jak wiele rzeczy i produktów można zaromatyzować. Przykładów stosowania takich praktyk jest wiele i pochodzą już z lat siedemdziesiątych XX wieku. Uwagę zwraca fakt, że sięgały po nie zwykle firmy mające już swoją renomę, które raczej nie musiały martwić się o brak rozpoznawalności swojego logo, o jego „uwidzialnienie w przestrzeni”. Właśnie w latach siedemdziesiątych linie lotnicze Singapore Airlines stworzyły swój korporacyjny słodki zapach świeżo ugotowanego ryżu, rozpylany w punktach sprzedaży. Nieco później w poczekalni linii British Airways na londyńskim lotnisku Heathrow rozprowadzany był inny specjalnie skomponowany zapach, który stanowi część celowo stworzonego środowiska. Tego typu praktyki służą wyznaczeniu granic i odgrodzeniu stref, które mają kojarzyć się z konkretnym produktem. Cytowani już autorzy wskazują, że następuje to „poprzez obecność np. targu rybnego, targu kwiatowego, targu bawełny made in China, targu herbacianego na Sri Lance, czy wreszcie targu garncarskiego, na którym dominuje zapach wypalonej gliny" (Szczepański, Ślęzak-Tazbir 2008, s. 35). Należy pamiętać o tym, że tego typu działania nie pozostają bez wpływu na funkcjonowanie miast, wokół których budowane są geograficzne archetypy zapachowe. Klasyczne przykłady to zapach Libanu (aromat cedru) czy zapach Wenecji (nieprzyjemny odór kanałów).

Prowadzone $\mathrm{w}$ przestrzeni miejskiej działania marketingowe mają wpływ zarówno na nadawców przekazów reklamowych (próbujących skupić na sobie uwagę innych i jednocześnie słabiej przez to rejestrujących to, co dzieje się dookoła nich), odbiorców (zmuszonych do racjonalnego gospodarowania swoją uwagą, a jednocześnie często będących przekaźnikami rozprowadzanych idei reklamowych) i samo miasto (w którym szklane konstrukcje stanowią narzędzie rozbudzania pożądania), które zaczyna kojarzyć się z konkretnym aromatem, tak jak Cieszyn kojarzony jest $z$ hasłem „Miasto pachnące magnoliami”). Istnieje wiele elementów - takich jak wielość dystraktorów, mechanizmy ekonomii uwagi, zasady rządzące skuteczną rozprowadzalnością idei czy powszechność bodźców działających na inne zmysły niż wzrok - które pozwalają powiedzieć, że widoczność w mieście nie jest jeszcze gwarantem sukcesu ekonomicznego. Szanse na taki sukces rosną wraz z uwzględnieniem innch elementów, takich jak umiejętne budowanie pożądania przez wizualne odsłanianie sposobów działania jakiejś usługi lub konstruowanie skojarzeń konkretnego produktu z miejscem, w którym można z niego skorzystać. Sposoby reagowania „użytkowników miast” na konkretne techniki marketingowe tego typu stosowane w przestrzeni miejskiej mogą stanowić przedmiot szczegółowych analiz. 


\section{BIBLIOGRAFIA}

Abercrombie Nick, Longhurst Brian, 1998, Audiences: A Sociological Theory of Performance and Imagination, Sage, London.

Ackerman Diane, 1994, Historia naturalna zmysłów, tłum. Krystyna Chmielowa, Książka i Wiedza, Warszawa.

Allor Martin, 1988, Relocating the Site of the Audience, „Critical Studies in Mass Communication”, t. 5 , nr 3 .

Batorski Dominik (red.), 2012, Cyfrowa gospodarka. Kluczowe trendy rewolucji cyfrowej. Diagnoza, prognozy, strategie reakcji, MGG Conferences Sp. z o.o., Warszawa.

Bernstein David, 2006, Billboard! Reklama otwartej przestrzeni, tłum. Ewa Ciszkowska, Wydawnictwo Naukowe PWN, Warszawa.

Certeau Michel de, Giard Luce, Mayol Pierre, 2011, Wynaleźć codzienność, t. 2: Mieszkać, gotować, tłum. Katarzyna Thiel-Jańczuk, Wydawnictwo Uniwersytetu Jagiellońskiego, Kraków.

Delerm Philippe, 2004, Pierwszy tyk piwa $i$ inne drobne przyjemności, tłum. Wawrzyniec Brzozowski, Wydawnictwo Sic!, Warszawa.

Fiske John, 2010, Zrozumieć kulturę popularna, tłum. Katarzyna Sawicka, Wydawnictwo Uniwersytetu Jagiellońskiego, Kraków.

Frank Robert H., Cook Philip J., 1996, The Winner-Take-All Society: Why the Few at the Top Get So Much More Than the Rest of Us, Virgin Paperbacks, London.

Gehl Jan, 2014, Miasta dla ludzi, tłum. Szymon Nogalski, Wydawnictwo RAM, Kraków.

Gergen Kenneth, 2009, Nasycone Ja. Dylematy tożsamości w życiu wspótczesnym, tłum. Mirosława Marody, Wydawnictwo Naukowe PWN, Warszawa.

Goban-Klas Tomasz, 1999, Media $i$ komunikowanie masowe. Teorie $i$ analizy prasy, radia, telewizji i Internetu, Wydawnictwo Naukowe PWN, Warszawa-Kraków.

Jakiel Małgorzata, 2013, Reklama w przestrzeni miasta - wybrane kwestie „widzialności billboardów”, „Przegląd Administracji Publicznej”, nr 2.

Jenkins Henry, Ford Sam, Green Joshua, 2013, Spreadable Media: Creating Value and Meaning in a Networked Culture, New York University Press, New York-London.

Kalbarczyk Marek, 2001, Polska pachnie dziś ładniej, „Newsweek”, 9 września.

Kobus Aldona, 2014, Tradycja badań popkulturowych w perspektywie anglocentrycznej, „Kultura Popularna", nr 1.

Krajewski Marek, 2005, Kultury kultury popularnej, Wydawnictwo Naukowe UAM, Poznań.

Krajewski Marek, 2007, Kultura dystrakcji - deficyty uwagi i strategie jej kumulacji (http://krajewskima rek.blox.pl/resource/Ekonomia_uwagi.doc).

Krajewski Marek, 2010, Przeciw inżynierii wizualnej. Ożywianie i uśmiercanie miasta, w: Ewa Rewers, Agata Skórzyńska (red.), Sztuka - kapitat kulturowy polskich miast, Wydawnictwo Naukowe UAM, Poznań.

Lasswell Harold D., 1948, The Structure and Function of Communication in Society, w: Lyman Bryson (red.), The Communication of Ideas, Harper, New York.

Maczuga Justyna, Przyłuska Jolanta, 2012, Jak zwiększyć widoczność swojej publikacji naukowej w internecie?, „Medycyna Pracy”, nr 63 (4), s. 391-393.

McQuail Denis, 1994, Mass Communication Theory: An Introduction, Sage, London.

Michalska-Dudek Izabela, 2009, Istota oraz możliwości zastosowania aromamarketingu na rynku turystycznym, „Prace Naukowe Uniwersytetu Ekonomicznego we Wrocławiu”, nr 50, Wydawnictwo Uniwersytetu Ekonomicznego, Wrocław.

Pacuska Maria, Czerniawska Dominika, Batorski Dominik, Błażewicz Marek, 2015, Dbałość o widoczność $w$ internecie jako wartość niematerialna wśród przedsiębiorstw województwa mazowieckiego uwarunkowania, „Economics and Management”, nr 1. 
Petty Richard, Rucker Derek, Bizer George Y., Cacioppo John T., 2004, The Elaboration Likehood Model of Persuasion, w: John S. Seiter, Robert H. Gass (red.), Perspectives on Persuasion, Social Influence, and Compliance Gaining, Pearson, London.

Putnam Robert D., 2008, Samotna gra w kręgle. Upadek i odrodzenie wspólnot lokalnych w Stanach Zjednoczonych, tłum. Przemysław Sadura, Sebastian Szymański, Wydawnictwa Akademickie i Profesjonalne, Warszawa.

Sandel Michael J., 2012, Czego nie można kupić za pieniądze. Moralne granice rynku, tłum. Anna Chromik, Tomasz Sikora, Kurhaus Publishing, Warszawa.

Szczepański Marek, Ślęzak-Tazbir Weronika, 2008, Miejskie pachnidło. Fragmentaryzacja i prywatyzacja przestrzeni w perspektywie osmosocjologicznej, „Studia Regionalne i Lokalne”, nr 2.

Szczurkiewicz Tadeusz, 1970, Wptyw prasy codziennej, w: Tadeusz Szczurkiewicz, Studia socjologiczne, Państwowe Wydawnictwo Naukowe, Warszawa.

Tarde Gabriel de, 1904, Opinia i ttum, tłum. Kazimiera Skrzyńska, Gebethner i Wolff, Warszawa.

Tudor Andrew, 1970, Film, Communication and Content, w: Jeremy Tunstall (red.), Media Sociology: A Reader, University of Illinois Press, London.

Welsch Wolfgang, 1998, Estetyka $i$ anestetyka, tłum. Małgorzata Łukasiewicz, w: Ryszard Nycz (red.), Postmodernizm. Antologia przekładów, Wydawnictwo Baran i Suszczyński, Kraków.

Wendland Paola, 2006, Jak sprzedawać więcej — sprzedawać zapachem, „Detal Dzisiaj”, nr 4.

Wernick Andrew, 1992, Promotional Culture: Advertising, Ideology and Symbolic Expression, Sage, London.

\section{IS VISIBILITY A GUARANTEE OF SUCCESS? THE EFFECTIVENESS OF MARKETING IN THE URBAN SPACE}

\section{Summary}

This article addresses the question of whether the visibility of specific brands in large cities always supports the economic success of the firms to which they belong. The author discusses the issue-which borders on sociology, psychology, and practical wisdom about marketing activities-in the light of four theoretical concepts. The first is George Frank's idea of the 'economy of attention', wherein attention is a good, which, contrary to other economic resources, does not have a substitute and is very hard to replace with anything else. The second concerns the type of audience reached by the visual marketing messages presented in cities. The third perspective is related to the concept of the 'culture of distraction', whose characteristic trait is the problem that individuals have in concentrating their attention on one object for a longer period of time. The fourth plane on which answers are sought is how the issue of visibility is overlooked in marketing campaigns. The key idea for this part of the analysis is Henry Jenkins' 'spreadability'. In conclusion, the author ponders the case of an ad campaign appealing to a sense other than that of sight. In this regard the author refers to the osmosociological perspective described by Marek S. Szczepański and Weronika Ślęzak-Tazbir, among others.

\section{Key words / słowa kluczowe}

visibility / widzialność; culture of distraction / kultura dystrakcji, economy of attention / ekonomia uwagi; viral marketing / marketing wirusowy; perspective of osmosociology / perspektywa osmosocjologiczna 